\title{
Exporting identity: Italians in London during the long 19th century
}

\author{
Robin Palmer \\ Department of Anthropology, \\ Rhodes University, \\ Grahamstown, \\ 8 Mariner's Cove, \\ Simon's Town, 7975, \\ Western Cape, South Africa \\ Email: r.palmer@ru.ac.za
}

\begin{abstract}
We live in a time of increased international migration and asylum seeking. Those involved have become scapegoats for nativists who support parties with promises to restore what they have lost through neoliberalism and globalisation. Neoliberalism may be of recent derivation, but it is derived from the liberalism and laissez-faire capitalism of the 'long 19th century' (1750-1914). Then, as now, the masses were 'pushed' to migrate by accelerated population growth and its political and socio-economic correlates. Focusing on London, the paper examines the experience of Italian migrants and asylum seekers in the UK of that period, who drew on the historic Italophilia of the British to advance their careers or causes. Collective reputation, so long as it is positive, can be an important resource for 'culture entrepreneurs' in migrant or refugee settings; it can take a long time to build but once established tends to be resilient and capable of innovative reinterpretation.
\end{abstract}

Keywords: Italian migration; Italians in London; long 19th century; street trades; catering; asylum seekers; culture entrepreneurs.

Reference to this paper should be made as follows: Palmer, R. (2018) 'Exporting identity: Italians in London during the long 19th century', Int. J. Business and Globalisation, Vol. 21, No. 3, pp.327-343.

Biographical notes: Robin Palmer is contracted to Department of Anthropology at the Rhodes University, from which he formally retired in 2012 following 33 years of teaching and conducting research in the Eastern Cape. He has retained an interest in the topic of his research for his doctorate from the University of Sussex, which was based on 18 months of fieldwork in the Italian community in London and a typical sending community in the Italy in the mid-1970s. He lives in Cape Town with his wife, Diana, now, close to two of their four children. 


\section{Introduction and background}

We live in a time of increased international migration and asylum seeking. The tragedies of the last few years, as human traffickers place tens of thousands of people at risk in unseaworthy vessels in the Mediterranean and elsewhere, have been well documented. The political fall-out of these new mass migrations continues with the rise of xenophobic right-wing opposition, its success signalled most dramatically in the cases of Brexit and the election of President Trump. The 'huddled masses' are no longer welcome, not least because they may include Muslim extremists. Nativist whites in Europe and the USA support parties that promise to restore what they have lost through 40 years of neoliberalism and globalisation; the media express fears that a new age of fascism could be dawning.

Neoliberalist ideology may be of recent derivation, but the very name is an echo of the liberalism and laissez-faire capitalism of another age, when the Industrial Revolution, following on the creation of the modern world system from 1600, transformed society (Wallerstein, 1980; Hobsbawm, 1963, 1975, 1987). This was the period cited in my title that Hobsbawm dubbed 'The Long 19th Century' - the period between the French Revolution (1989) and the First World War (1914-1918), and that Stearns (2012) stretched to commence in 1750 , because it is artificial to confine it to a century. Then, as now, it was a time of migration, 'pushed' by the correlates of accelerated population growth - pressure on resources, poverty and political instability. Tranter (1994, p.37) has documented an annualised average increase in the population of Europe that almost doubled to nearly one per cent between 1800 and 1850 compared with the preceding half-century, which itself represented a marked increase on the period 1600 to 1750 , when the annual average increase was only $0.38 \%$. The steadying of the increase after 1850 reflects the impact of the Atlantic migrations - a still unsurpassed movement of people overseas that would involve more than 50 million Europeans between 1821 and 1915 (p.40).

Huge and unprecedented as the Atlantic migrations were, migration within Europe was much greater: migration between regions in the same country, e.g., harvest labour, had long occurred, but it acquired a more rural-urban character as industrialisation spread; cross-border migration within Europe was also increasing, facilitated by the Congress of Vienna (1815) that ended the Napoleonic wars. A period of peace ensued: travel was easier and safer than before, but it also became more necessary due to population pressure and the economic depression that followed the Napoleonic wars. The main destination in the earlier part of the 19th century was France and in the latter part it was Germany - England already had a desperate and bountiful labour source that it controlled: Ireland. This did not mean that the UK in its early industrial revolution had no opportunities for foreigners other than Irish, but the existence of that reserve army did constrain the kinds of opportunities that were open to aliens [Palmer, (2007), p.365].

The great international movement of labour to capital in the long 19th century, motivated by the needs of industries and infrastructure expansion (such as railways) that were so much more labour intensive than today's, was not some abstracted flood but rather an aggregate of many streams, and because it was a movement of human beings and not water, the participants had some agency: 


\begin{abstract}
"There was an element of choice on the part of old world peasants and tradesmen who journeyed to the European and American cities. They were not only the dispossessed of Europe; they had to come to terms with economic modernisation, which they did by becoming petty entrepreneurs. [ ... ] These migrants, who invariably hailed from rural towns or villages, had a sense of economic possibilities, of markets for their goods and services, because for centuries they had maintained a dialogue with urban centres. With the improvement of transportation and communications in the nineteenth century the urban centres with which they had a rapport could be even farther from the migrants' home town." [Zucchi, (1992), p.6]
\end{abstract}

For not a few of the increasingly constrained marginal folk of Europe, these links with urban centres included earlier travellers from their regions now trying to make a living in London, the phenomenon of their age. The UK was in the vanguard of the unprecedented changes that took place in Europe after 1750, known as modernisation. The revolutions in agriculture, transport, industry and finance were experienced earliest in the British Isles (Hobsbawm, 1962). The impact on London was rapid and far-reaching. In 1801, when the first national census was taken, London's population was just under one million $(958,863)$, one tenth of the population of England and Wales; but by 1901 it was $6,586,000$ or one-fifth of that population. While the bulk of the increase came from internal rural-urban migration and migration from Ireland, the foreign-born were also making their contribution, doubling from 26,000 to 48,000 between 1841 and 1891 [Inwood, (1998), pp.411-412].

In general, relations among London's increasingly cosmopolitan population over the 19th century were cordial, but there were two exceptions: the Irish and the East European Jews. The Irish came in bursts following the great famine in the 1840s and a depression in the agricultural sector in the 1870 s and were not well-received. Later, in the 1890 s, Eastern European Jews fleeing from the Tsar's pogroms began arriving in London at a rate of between 2,000 and 7,000 a year. Though they settled mainly in the East End, close to the docks where they had arrived, they attracted xenophobia (pp.413-416).

Victorian London is conventionally portrayed as a centre of commerce and finance, then as now, but the same forces of industrial and imperial expansion that were turning the docklands into the World's greatest port and 'the city' into a global centre of finance and insurance, were also permitting other forms of industry to flourish in the capital: by 1851 London had 373,000 workers engaged in manufacturing (pp.465-496). As the capital, London's workforce also included the highest proportion of government employees, professionals, wholesale and retail dealers, transport workers and domestic servants in the land. Related to its high rate of economic expansion, London also offered plenty of employment for architects, contractors, building and decorating workers of all levels of skill, and those who made furniture and fittings for both offices and homes. Ever since the restoration of the Monarchy in the early 1600s the aristocracy and landed gentry had maintained a strong seasonal presence in London. Now, in addition to 40 to 50 aristocratic mansions, there were about 350 large town houses in Mayfair, St. James or Belgravia accommodating, besides these seasonal visitors, a new capitalist class of permanent residents. The seasonal demand of hundreds of landed families for transport, accommodation, servants, entertainment, food, clothes and luxury goods had stimulated trade in London since the 1600s, now the resident rich reinforced that source of wealth, 
joining in the 'London season' along with colonial officers and administrators on 'furlough'. Aping the extravagances of the aristocracy, this enlarged bourgeoisie supported a major expansion of retail shopping including such innovations as the arcade and the department store [Inwood, (1998), p.641]. They also supported the gentlemen's clubs, the great hotels, the opera, the ballet, the West End theatres and the concert halls that were mushrooming in those times. Under the Prince Regent and Victoria, the court became more central again (following its decline under the Germanic Hanoverians) and the Season included sporting events in and around London such as horse-racing, cricket, and boat races, with different demands on the wardrobe. Meanwhile, the petite bourgeoisie and the upper working class, with increased leisure-time in an age of reform, sought diversions of their own. They were catered for by the proliferation of 'pubs' and eateries and as well as music halls, pleasure gardens, working-men's clubs, and race courses - and the numerous street traders and entertainers [Ackroyd, (1969), Chs. $15-17 ; 33-38 ; 41-42]$.

All of this is not to deny the Dickensian side of London, the poverty that most native Londoners - and most immigrants - endured along with periodic epidemics of typhoid that was documented by Mayhew (1851-1968). My focus on development in London in that period, the creation of economic opportunities of every kind, is to provide a sense of the incentives that persuaded so many migrants, both internal and international, to 'seek their fortunes' in London. These newcomers included an unprecedented inflow of people from Italy who are the focus of this paper.

Why is this focussing relevant, let alone interesting, to contemporary readers of a journal concerned with business and globalisation? I believe it is helpful to be reminded that ours is not the first or the only age of globalisation even if it is unprecedented in terms of scale or integration. The long 19th century also produced globalisation and change, if at a slower rate and mainly within empires, such as the vast British Empire (Hobsbawm, 1987). Although wars declined after 1815, political instability generated equivalents of the modern asylum seekers, not least Italians of greater and lesser fame and distinction who were involved in the struggle to unify Italy (Wicks, 1937; Palmer, 1981, Part 3). Whether voluntary or forced migrants, many Italians chose London (though other more proximal European countries would also have taken them) because of an extraordinary history of connection between the two countries, as I shall show. Italian migration to Britain is an example of how foreigners, always regarded with suspicion by natives until they prove themselves, can establish a positive legacy, and subsequently draw on it to advance their careers.

\subsection{A note on terminology}

'Italy' and 'Italian(s)' are terms not without issues. Denis Mack Smith (1959, pp.1-9) commences his Italy: A Modern History with: "Until 1860, Italy was used not so much for a nation as for a peninsula ...," uncentralised since the Romans and made up of city-states, kingdoms and areas colonised by the French, the Austrians and the Spanish. Only following the Risorgimento did the geographical and political entities become fused. Technically, 'Italian', then, is only a geographical description until 1860, when it also described nationality or citizenship. This latter meaning, which is the most understood today, can be hampering. I found, when researching the Italians in London and Italy in the $1970 \mathrm{~s}$, as others before me, that I needed a term that would include the British-born children and even grandchildren of the original migrants. This was a 
community that, in the mid-20th century, tended to assimilate very slowly into British society, so to use the term 'Italian' implying only the Italian-born or Italian nationals, could be misleading, not least when calculating the size of the community. Others got around the problem with the term 'Italianates' (Garigue and Firth, 1956) but I was too conscious of the term's primary meaning as a descriptor of Italian style, originally referring to objects, to want to use for people who I had come to know so well during 18 months of fieldwork. Instead, I came up with 'Britalians' (Palmer, 1981, 1984). However, in the light of subsequent developments in information technology (which were unimaginable at the time) I have come to realise that the coining of a neologism such as Britalian was a mistake: it makes any publication referring to the Italians in Britain in terms other than 'Italian' invisible to research engines. For that reason, but also because this article deals with the past, when a paucity of good sources makes it impossible to be certain about the post-migration demography and social organisation of people who anyway held a variety of citizenships before unification in 1860, it makes sense to use 'Italian', though in the geographical sense of origins rather than nationality.

\section{Italians in Britain: the legacy}

Italian migration to Britain has never been of sufficient volume to draw the kind of attention that their migration to Brazil, Argentina, the USA, Canada or Australia has attracted (Foerster, 1919; Price, 1963; Balletta et al., 1978). Even when Italian migration to Britain was growing and becoming more of a mass phenomenon in the latter half of the 19th century it was masked by the more sudden, numerous and problematical influxes of Irish and Eastern European Jews mentioned above. These distractions from the increasing arrivals of Italians drew xenophobic fire from them. Another advantage the Italians enjoyed was a generally favourable attitude on the part of the natives, not necessarily to them as individuals, but as representatives of a culture that had long been respected by Britons who were for a long time subject to it.
"It is no accident that the story of London begins with "foreigners". There was no settlement at all on the banks of the Thames before the arrival of the Romans. Londoners owe their city, so to speak, to the Italians, and its whole development ... is a tale of the successive migration of wave upon wave of outsiders who have made their mark on London, given it their own distinct flavour, while at the same time becoming assimilated to the metropolitan melting pot." [Porter, (1968), p.26]

Even after the Romans left in 410AD people from the Italic peninsula continued to influence British culture. Pope Gregory and subsequent popes took an interest in converting the non-Romanized, pre-Christian inhabitants of the British Isles to Christianity. To achieve this, the Vatican deployed mainly Benedictine and Franciscan friars to make and keep the British Isles Catholic and incidentally, to participate in the production and export of fine wool [Palmer, (1981), p.119]. As Britain became more centralised in the Middle Ages and the wool industry grew and became even more valuable as an export commodity, an early, more localised form of modern neo-colonialism emerged: Genoese and Venetian traders set up bases in Southampton and London and bankers from Lucca, Lombardy and Florence established branches in London from the 13th to the 15th Centuries [Foerster, (1919), p.203; Braudel, (1982), p.391ff]. Marin (1969, pp.11-12) notes how the long presence of the bankers is 
commemorated in the name of one of the principal thoroughfares in The City of London, Lombard Street. The term 'bankrupt' is derived from the Italian phrase banca rotta (broken bench) after the ceremonial axing of the bench from which a banker operated in a banking hall in a case of insolvency; the denotation of pounds, shillings and pence as $£$ s. d. comes from the Italian denotations lire, soldi, denari introduced by those bankers. The counter-trade brought by the merchants was in finished wool cloth and silks, and this also attracted tailors and hatters, mainly from Milan, who were experienced in the use of these fine cloths, and stimulated local manufacture of them. In another linguistic echo, these artisans were known as Milleners by the English, referring to their origins, though the term has come to denote hat-makers only, of any origins (p.12).

British power and nationalism increased under the Tudors. The Italian bankers were evicted from London; Henry VIII broke with the Vatican and dissolved the monasteries. Yet Italy's association with Classical civilisation and now as the birthplace of the Renaissance maintained its prestige in the eyes of Britons despite subsequent economic decline and internecine conflict in Italy. Important for Italians who might seek to escape their homeland under these conditions was the admiration of the English for Italian craftsmanship and creativity. Odericus and Petrus Romanus (their names Latinized) worked on the tomb of Edward the Confessor and produced the splendid mosaic floor in Westminster Abbey (p.13). Later, Palladio influenced English classicism in architecture, as seen in the work of Vanbrugh, Inigo Jones and Adam on many 'stately homes'. Italian painters, sculptors and decorators - too numerous to mention individually - were recruited to create Italianate style for the interiors of these buildings, the inspiration for which was generated in 'The Grand Tour', a popular rite de passage for the scions of noble families. These young men spent several years travelling on 'The Continent' with a tutor and servant, soaking up culture and collecting items for the country houses they would one day inherit [Towner, (1985), pp.297-333].

An appreciation of Italian music and theatre, nourished on the tour, soon became pervasive among the London elite (Veblen 1899). In response, four generations of the Ferrabosco family dominated the musical scene in London from the 17th century, and Jacopo Peri introduced the melodrama to the UK. Composers in Italy were already combining melodrama with music to develop 'opera', and this new form was introduced to Londoners by Ottaviano Lotti, to great acclaim, leading to the foundation of The Italian Opera House in Covent Garden and creating opportunities for subsequent directors and numerous musicians and singers of Italian origin [Marin, (1975), p.12].

Italy and the Italianate continued to attract English leaders in culture and politics after 1800. Byron, Shelley and Keats; Ruskin, Dickens and Browning - each in their own way conveyed their admiration for the Italianate to the British public. William Gladstone (1809-1898), who dominated British politics for most of the century, was an Italophile of note. In the 1830s he toured Italy his brother and retained an interest in Italy ever after. In 1850 he visited the prisons of Naples, crowded with political dissidents since the revolts of 1848. The experience transformed him from Tory to Liberal, and increased his support for Italian exiles already in London [Wilson, (2002), Ch. 7; and see below]. While direct cultural transfers from Italy to the UK still tended to involve elites, they also filtered downwards: 'Punch' as both the title of a popular long-running journal founded in the 19th century and the main character in the 'Punch and Judy shows' is derived from Pulcinello, a character in the Commedia del Arte that was brought to the UK in the 18th century; and there are many other similar examples [Palmer, (1981), pp.15-18]. 
This is the legacy of every Italian who has come to London since then, whether he or she knows about it, or chooses to exploit it, or not. But educated Italians in particular have always been aware of their special relationship with the UK, not least its Capital, and they make their fellows aware of their legacy (see, e.g., Marin, 1969, 1975). For a positive tradition is a scarce resource, something migrants usually lack in the eyes of their 'hosts' and which is useful to those who make a living whether in employment or self-employment. Italianate influences on British society at all levels, whether the public realised the origins of these or not, became an important factor in the occupational choices made by Italian migrants. A positive regard for Italy and the Italianate provided scope for what I have termed 'culture entrepreneurship' as a survival strategy for the most desperate, and as a promoter of careers at all other levels (Palmer, 1981, 1984, 2007).

\section{Italians in Britain as 'culture entrepreneurs'}

Italian migrants have long exercised agency in an entrepreneurial direction, frequently involving the recruitment of others. This behaviour is a major driver of their distinctive 'chain' migration (Price, 1963). Among Italians in the UK the emphasis, historically and up to the present, has been on self-employment, which was not characteristic of migrant-generation Italians in other receiving countries, who were in the main unskilled or semi-skilled labourers, at least to begin with. Entrepreneurship has also been a characteristic of later migrants and asylum-seekers to the UK, mostly Chinese, East Asians and East African Asians (see, e.g., Watson, 1975; Werbner, 1984; Barrett and McEvoy, 2006).

In the UK, in the 19th century, some of the humble street-traders could formalise their trades, for example, in ice-cream; some of those in employment, for example, as waiters, were working towards eventually having their own business, and many of them succeeded. Even where there was little profit, there was prestige in being independent, not least to rural Italians to whom working under others is anathema [Palmer, (1977), pp.250-251]. But it was also the case that there were few jobs open to Italians in the UK: the early development of trade's unions protected valued working class jobs for the British and custom and affinity the less desirable labouring jobs for the Irish (Aldritch et al., 1984). Yet Italians kept on coming and seemed to enjoy the opportunities for self-invention and entrepreneurship that the UK, and particularly a booming London, offered in the long 19th century. Accordingly, Italians tended to cluster in occupations that were either Italian in origin or had come to be associated with Italians in the UK. They became entrepreneurs of their own culture, including how their culture was perceived and received by the British, and by their efforts they in turn provided scope for their countrymen who followed them to London.

In the subtle understanding of anthropologist Fredrick Barth, an entrepreneur is not so much a person or even an entire role or status but rather an 'aspect of role' Barth (1963, p.5). One can thus be entrepreneurial whatever one's job description or even when unemployed; it is, quintessentially, a manifestation of an attitude, an approach to life. Barth (1969) also theorized culture and ethnicity, particularly how and why the boundaries between ethnic groups are created and maintained. While Barth himself did not combine his conceptualisation of ethnicity or culture with that of entrepreneurs, I 
thought doing so could supply answers to the question of why Italian migration to the UK has taken a distinctive form beyond the more conventional notion of 'opportunity structure' (Hannerz, 1974). This model of the 'culture entrepreneur' is not limited to the case before us - migrants of any origins frequently transfer what is ordinary or every-day at home to where it is scarce or unknown abroad and, if it turns out to be positively received, they exploit it. It can be chop suey, curry or kebabs as much as pizza or ice-cream. As they do so, they find themselves also exploiting their identification with the product and the presumption in the host population that they are uniquely qualified to do so [Palmer, (1981), Ch. 4, (1984), (2007)]. Ethnic entrepreneurship as both a global reality and a concept has expanded considerably since I confronted it in the 1970s (see Jenkins, 1984; Dana and Morrisn, 2007; Light, 2007; Volery, 2007).

\section{Emigration and Italy in the long 19th century}

Modernisation and population increase underlay the literal and metaphorical revolutions in Europe that also affected other regions after 1750, these forces were revolutionising the old ways of Europe's peasantries [Handlin, (1951), Ch. 1]. More children surviving to adulthood meant not only more mouths to feed, but also pressure on resources over-cropping, over-grazing and land alienation. In Italy and other Mediterranean countries where custom and the Law enjoined partible inheritance more children surviving childhood than would replace their parents caused patrimonies to shrink in every generation until they were of sizes that could not support a family. Then there were catastrophes that could tip such penurious households into debt - landslides, earthquakes, illness or injury. In Italy, which lacked both extensive agricultural land and the raw materials for industry, population increase was less sustainable than, say, France, and emigration of all kinds increased massively over the period [Tranter, (1994), pp.45-46]. After Unification emigration from Italy went from an estimated 100,000 a year, mainly to other European countries, to more than 500,000 a year in the decade preceding 1914 (p.41). Yet, as already suggested, this was no headlong flight of the masses that somehow excluded agency. Documenting the tumultuous Italian migrations happening around him before the First World War, Robert Foerster, the Harvard economist, emphasized the agency of his Italian subjects. In a typical scenario,

$$
\begin{aligned}
& \text { "... Boys usually begin with work in the furnaces, in Hungary perhaps, or } \\
& \text { Germany. A year or two later, drawn perhaps towards the primal trade of all, } \\
& \text { the mason's, they become hod-carriers, next undertake the coarser forms of } \\
& \text { masonry and finally the more skilled work with cement and stucco. The winter } \\
& \text { season may be devoted to the study of a foreign language or attendance at a } \\
& \text { school where the finer technique of the mason's art is taught. In time many will } \\
& \text { become contractors, supplying troops of other masons and risking their own } \\
& \text { capital. By a similar procedure, the other sorts of skilled workmen may be } \\
& \text { developed." [Foerster, (1919), p.123] }
\end{aligned}
$$

If they worked well, with unusual skill, as was likely, then Italian contractors would be preferred in the countries where they worked; the contractors were entrepreneurs and culture entrepreneurs combined.

Accelerating economic and social change in Italy was accompanied by political upheaval. The puppet state that Napoleon Bonaparte imposed on Italy between 1789 and 1815 shook the territory out of feudal torpor - for a while. The restoration to foreign rule 
thereafter, and the return of aristocratic privileges and power, was a provocation to Italians who had experienced 26 years of Napoleonic reform, some industrialisation and a wider spread of affluence. An emergent commercial middle-class was not content to negotiate a peninsula divided into eight separate states, each with its own currency, measures and tariff barriers [Smith, (1959), pp.8-9]. The post-Bonaparte involution provoked a dormant spirit of Italianità, or national identity that became the Risorgimento. Uprisings followed in 1820-1821 in several Italian cities, but they failed through lack of cohesion and coordination. Greater unity characterised the revolution of 1848 , but it too ended in disputes on a regional basis, and old regimes were not toppled. With every set-back, asylum seekers poured into other European countries, notably France and England. Eventually, Giuseppe Mazzini, the great driver of the insurrection, Giuseppe Garibaldi, the guerrilla leader, and Camillo Benso, Count of Cavour, the politician, prevailed, securing unification in 1861 (pp.11-16).

The Risorgimento exacerbated the economic problems of Italy, and so emigration as a response to the push factors mentioned above could only increase. Instability also disrupted the lives of middle-class people: academics, because many of the activists were students; small businessmen and artisans, whose normal lives were disrupted. In short, the period saw not only an increase in Italian emigration but also a great diversification in terms of destinations and migration types. Whether destitute economic refugees or literal refugees or professionals seeking advancement, London offered many attractions for Italians seeking escape from troubles at home.

\section{Italian exiles and itinerants}

In addition to ordinary educated or skilled Italians seeking a measure of stability and advancement in their careers during the Risorgimento, and the asylum seekers themselves, economic migrants of the most desperate kind, the surplus sons of downtrodden or landless peasants also migrated. In this section, we examine them separately but also in interaction. For while the most distinguished of the exiles found employment or attracted patronage, the rank-and-file frequently found themselves sharing the same space with countrymen of the lowest class who became itinerants ending up in the teeming 'Little Italy' of Clerkenwell (Marin, 1975; Wicks, 1937). This district had seen the growth of the watch-making trade in the 18th Century, attracting skilled artisans from all over Europe [George, (1925), ch. 4]. Italian artisans, diversifying into various forms of instrument-making, such as thermometers and barometers, were the founders of the Italian community there, but by the turn of the 19th Century they were rapidly outnumbered by less-skilled, more desperate street-traders, crowding the limited accommodation available in this small borough.

The Italian itinerants, who came and went through the relaxed border controls of the times, are hard to enumerate. Foerster $(1919$, p.205) estimated from a variety of Italian sources that there were about 2500 Italian itinerants in London towards the end of the 19th Century, but their way of life was already waning by then (see below for details). Street musicians, the largest category, came for the most part from the Duchy of Parma, and from Liguria, in the district of Genoa. A more sophisticated form of itinerant came from around Lake Como, "confecting simple thermometers from barrows, before the eyes of the passing British, sealing the mercury into calibrated glass tubes with the heat of a 
portable burner," [Palmer, (1981), p.160], and likewise the sellers of plaster figurines from villages near Lucca. The Liri valley, between Rome and Naples, was the original source of the ice-cream makers, who either bore insulated containers from a strap or operated barrows. Theirs was a true gelato, made freshly in their lodgings in Clerkenwell every evening (Sponza, 1988). Later in the century, from a single valley in the Trento, came the knife-grinders, pushing their barrows mounted with a grind-stone and tools across France and parking them outside restaurants and shops and the servants' entrances of the great houses in London, sharpening knives and scissors [Palmer, (1981), p.159].

Details of the itinerants' way of life are scarce - being mainly illiterate they did not leave records in the way of diaries or memoirs - but Zucchi (1992) gleaned information on the musicians in three cities including London and Farley (1969, p.62) describes the man from Parma who had earned three shillings a day ( $£ 52$ a year, assuming a six-day week and no holidays) from previous efforts. He managed to save the $£ 35$ needed to buy a set of mechanical figures, calculating that this investment would double his income. If his luck held, he planned to retire to Italy in a few years. There was nothing particularly Italian about this ambitious venture, except for the man's origins, but it was decidedly entrepreneurial, and the more Italians who imitated him, the more it would have been regarded as 'something Italians do', like chimney-sweeping and knife-grinding, which are not intrinsically Italian inventions. More calculated to appeal to the Italian stereotype were the street musicians who played the zampogna (Italian traditional bagpipe), flute or barrel organ, with or without the traditional monkey. Lest the association be lost on the audience, they tended to wear traditional Italian regional or other distinctive clothing. Likewise, the ice-cream sellers and the instrument makers.

The downfall of most of the itinerants, was that many of them had child adjuncts. As Zucchi (1992) has shown in detail, Italian itinerancy in the Victorian era depended heavily on a system by which boys and girls were contracted to a master or padrone for 15 to 36 months by their families in rural Italy. The role of the smaller children was in part to divert with tame mice, squirrels, monkeys, or dancing dogs while their master entertained with musical instruments. As the children grew up or became used to the trade, they would learn to play instruments themselves (pp.16-17). From an Italian perspective, apprenticing children at a young age was quite normal, and mostly the padroni were relatives or paesani (fellow villagers) who usually treated them kindly, within the limits of affordability; however the occasional case of abuse came to public attention through media that were already appreciating that scandal sold newspapers (pp.1-3). In 1873 legislation was enacted in Italy that forbad the export of child labour and in the UK distaste for child labour was part of a campaign to legislate against itinerancy. Moreover, as the numbers and success of some itinerants grew, the British Association of Costermongers, began petitioning Parliament to limit foreign street traders, such as the Italians. Their intervention was taken seriously, resulting in a Select Committee, then a Royal Commission, leading to legislation against the use of child labour (1889) and eventually the Aliens Order of 1905 (p.4).

Not all itinerants returned to Italy or found other forms of work. Some, notably the knife grinders and ice-cream sellers, who did not generally rely on child adjuncts, mutated into formal business-people, with premises. When, in accordance with the Aliens Act of 1919, Italian immigrants to Britain required work permits, formal employers in registered cutlery or ice-cream companies could apply for permits for their relatives or paesani (fellow-villagers) - and the migrant chains that fuelled these industries persisted over the decades [Palmer, (1981), p.159, p.187). 
The first Italian asylum seeker of the Risorgimento to arrive was the poet, Ugo Foscolo who came to London in 1816 (Franzero, 1971). Many followed after the failed insurrections of 1820-1821, and again after the revolt of $1848 .{ }^{1}$ As a category, they appealed enormously to British Romantics and to elements of the Whig Establishment, but in practice the potential patrons, as members of the upper classes, tended to favour the more 'respectable' of the exiles, implying upper-class, educated moderates such as Foscolo, Rossetti ${ }^{2}$, and Mazzini. By no means were all of those in the struggle for Italian Unification, including Garibaldi himself, educated or skilled people, and exiles of lower class backgrounds, unable to find employment or patronage, became charity cases [Foerster, (1919), pp.203-205]. Some of those with education held themselves aloof from the craftsmen and itinerant traders, but not Mazzini, the philosopher of the Risorgimento, with early socialist leanings. He actively sough support from influential Britons for the Republican cause, but did not neglect his proletarian co-nationals in London. After only three years in the country, with the financial assistance of English patrons, Mazzini founded a Union of Italian Workers and, later, a free school for Italian children in Hatton Garden. These initiatives collapsed without his leadership after he returned to Italy in 1848, but in 1851, when he returned to London, he launched two new associations: The Friends of Italy and La Società per il Progresso degli Operai Italiani in Londra (Association for the Advancement of the Italian Workers in London). Garibaldi endorsed the latter association on his triumphal visit to London in 1864, and ever afterwards it was known as The Mazzini-Garibaldi Club [Marin, (1975), p.18ff; The Mazzini-Garibaldi Club of London, http://www.mazzinigaribaldiclub.org/].

Mazzini also lent his prestige and support to the founding of the Italian Catholic Church of St Peter, in Clerkenwell Road, an initiative of the canonized Vincent Pallotti, staffed ever since by Italian priests of the Pallotine Order. An impressive building in a distinctive Italian style, it was modelled on a basilica in Rome and must have been a source of great pride to its Italian parishioners. Mazzini's charitable interventions set a good example, and in 1884 the Italian Hospital was founded by Giovanni Battista Ortelli, a businessman who had noticed how his co-nationals struggled in English-speaking mainstream hospitals (Lost Hospitals of London: Italian Hospital, http://ezitis.myzen.co.uk/italian.html). Most of the exiles had returned to Italy by the time these facilities became available, but there were plenty of other Italian migrants in London to avail themselves of them, and take pride in these Italianate buildings staffed by dedicated Italian priests and nuns. I have discussed elsewhere [Palmer, (1981), Part 3] the crucial role of these and other 'community structures' for turning a disparate 'collectivity' of Italians into a community, and maintaining their ethnic distinctiveness, pride and networks, both in the period described and again, after 1945, when a new wave of Italian migrants sough succour and connections.

The departure of most of the exiles and the waning of itinerancy was by no means the end of an Italian minority in the UK; it was rather the beginning of a strong tendency that came to dominate the London community - the shift to catering. Italian migrants were taking advantage of the new opportunities that were multiplying in London after midcentury that I have described above. Vacancies too numerous for the natives and even the Irish to fill were opening in the grander private houses and particularly in the many hotels and restaurants in the booming city. Then as now, it was a that was not unionised and accommodates foreigners. For the ambitious, this sector offered an opportunity to save and to learn English, against the day when one might open 'a place of one's own'. 


\section{Culture entrepreneurs in the services sector}

Given our understanding of entrepreneurship as an aspect of role rather than a person or an occupation (above), it becomes possible to view even a lowly employee, such as a waiter in a hierarchical occupational structure such as the Victorian hotel, as an entrepreneur, a culture entrepreneur. Dealing with the public, as well as British managers, he (in the larger establishments waiters were always male) was well positioned to employ qualities and opportunities available to him to advance his career. These included the way he was perceived, not as a person so much as a type constructed of his ethnicity and how this was understood in the context in which he operated. That Italian waiters were excellent culture entrepreneurs from the outset in London is evidenced by Sir George Smith, Chairman of the Savoy hotel group before the First World War, who is on record as having the following motto, communicated in French which was the Lingua Franca of hoteliers in those times: "Dans la sale les Italiens, dans la cuisine les Français" [Palmer, (1981), p.171].

How did Sir George come to this understanding? How did Italian waiters achieve this ethnic monopoly of the waiter's role? Sir George and his waiters are no longer around to be interviewed, and records are scarce, but the autobiography of Peppino Leoni, born in 1892, i.e., 22 years before the end of our period, provides some insights. Leoni had a lengthy career as a waiter in London before eventually opening his own, very successful, restaurant, Leoni's Quo Vadis. In his autobiography [Leoni, (1966), p.82] he links the success of the Italian waiter to the legacy of centuries of feudalism and foreign misrule in Italy: "They had learned to be servile without loss of pride, to be humble without fawning, and they applied this knowledge to their work." Born a little earlier, in 1884, the English writer and extensive traveller, Maugham (1952), had a similar but less self-flattering explanation rooted in the extensive continental travel of the first wave of affluent British tourists, motivated by the cultural legacy of the Grand Tour to visit Italy, who were of the same class and experience as most of the customers of the grand hotels of London:

“... [I]t never entered [English tourists'] heads that the courtesy they received, the bows, the smiles, the desire to please were owing to their lavish spending, and that behind their backs the 'natives' mocked them for their bad manners, their insolence, their silliness in letting themselves be consistently overcharged, their patronising tolerance ...."

Of course, the two explanations are not mutually exclusive; the complexities of Italian society and likely prior experience with tourists helped would-be waiters to negotiate the dining rooms in London and the Byzantine rank order of the hotel trade and, perhaps, to supplement their meagre wages by angling for tips and otherwise exploiting the opportunities that came with the occupation (Mars and Nicod, 1984). Leoni (1966, p.42) knew rapid economic progress was possible from certain encounters, beginning when he was ten (in 1902):

"I would often meet, in the narrow streets of Cannero, well-dressed strangers and wonder who they were. Cannero [a village on Lake Maggiore] was popular with the English in those days, but these men were not English. They were a little too formally dressed ... and they greeted people in the local dialect. I asked the restaurant [for which he ran errands] chef who they were and he told me they were natives of Cannero who had gone to England and made fortunes as restaurateurs ...." 
The Aliens Order of 1911 may have restricted the immigration of the unemployed or self-employed, but those recruited by hotels and restaurants that were formally set-up could still enter Britain on work permits, and Italians continued to be preferred as waiters well into the 1970s even though they had become scarce following the Italian 'economic miracle' of the 1960s and the rise of mass tourism, which provided more opportunities at home [Nichols, (1973), Ch. 9]. Then, as I discovered in the field, Italian waiters could command (informally) twice the salary of a Spanish or Portuguese of similar experience [Palmer, (1981), pp.201-202], and this had most likely been the case since Sir George Smith's day. This advantage accelerated their ability to save and eventually establish restaurants or cafés of their own or in partnership. Independence had implications for their capacity to support and maintain contact with their home communities, as I could verify in my second field site, a small parish in Italy (see Palmer, 1980, 1991).

\section{Italians in the UK in the long 19th century: an overview}

In 1895 the Italian Chamber of Commerce published a directory of 'Commercial and Professional Italians resident in the UK' (Elenco Generale degli Italiani Residenti nel Regno Unito, 1895). These were the hey-days of Italian migrants responding to the opportunities opening up in the tertiary or catering/services sector, particularly in London. It was still easy to enter the UK and not difficult to exploit the favourable reputation of Italian waiters.

Table 1 reflects both tradition and transition in the Italian community in London and in the provinces where there was less competition and thus more scope for the distinctive services of Italians, one of the most popular of which was the provision of ice-cream.

The overwhelming majority of businesses and professional services recorded in the Directory were by now in retail or wholesale catering. Some, regardless of original occupations, were serving the British public directly (as shopkeepers, confectioners and hoteliers) and indirectly (as importers and wholesalers supplying Italian and other catering business). 'Traditional' occupations for Italians in the UK persisted, and had become formal enough to appear in a directory - those of artists, sculptors, tailors and dressmakers, hairdressers, modellers, musical instrument makers, barometer- and thermometer-manufacturers and music teachers. Interestingly, most of the trades that are found almost as frequently in the Provinces as in London are the most long-established of Italian occupations in the UK, including: barometer makers, boot and shoe makers, dressmakers, modellers and figure makers, looking-glass and frame makers, and teachers of music. Other categories simply meet universal needs, such as apartments and boarding houses, beer retailers, commission agents, confectioners, fruiterers and greengrocers and general merchants, of which last there were now more in the provinces than in London.

The upward economic and social mobility in a range of sectors that the directory records is a function of decades of entrepreneurship. Besides the efforts of individuals, it reflects the support and the co-operation between in some instances radically different classes of people who were in London for very different reasons and purposes, not least the early collaboration of the exiles and the itinerants, generating institutions that were useful to catering workers and the independent business people many of them became. 
Table 1 Occupations of commercial and professional Italians in the UK with ten or more exemplars in London

\begin{tabular}{|c|c|c|c|}
\hline Occupations & London & Provinces & Total \\
\hline Apartments and boarding houses & 37 & 18 & 55 \\
\hline Artists & 27 & 1 & 28 \\
\hline Barometer and instrument makers & 11 & 9 & 20 \\
\hline Beer retailers & 12 & 7 & 19 \\
\hline Boot and shoe makers & 11 & 7 & 18 \\
\hline Butter, cheese and eggs wholesalers & 16 & 1 & 17 \\
\hline Cabinet makers & 16 & 6 & 22 \\
\hline Chandlers & 15 & 5 & 20 \\
\hline Commission agents & 10 & 14 & 24 \\
\hline Confectioners & 187 & 130 & 317 \\
\hline Dressmakers & 16 & 8 & 24 \\
\hline Dining and refreshment rooms & 148 & 69 & 217 \\
\hline Fruiterers and greengrocers & 20 & 14 & 34 \\
\hline General merchants & 34 & 36 & 70 \\
\hline Hairdressers & 34 & 11 & 45 \\
\hline Hotels & 32 & 7 & 39 \\
\hline Ice merchants & 11 & 4 & 15 \\
\hline Modellers and figure makers & 15 & 34 & 49 \\
\hline Musical instrument makers and importers & 17 & 6 & 23 \\
\hline Laundries & 11 & - & 11 \\
\hline Looking glass and frame makers & 20 & 11 & 31 \\
\hline Provision merchants and importers & 50 & 11 & 61 \\
\hline Sculptors & 13 & 5 & 18 \\
\hline Tailors & 17 & 7 & 24 \\
\hline Teachers of music & 41 & 21 & 62 \\
\hline Wine merchants and importers & 32 & 11 & 43 \\
\hline Total & 853 & 453 & 1306 \\
\hline
\end{tabular}

Note: *Italian Chamber of Commerce (1895)

\section{Conclusions}

Italian migration to the UK has never been impressive by any quantitative measure; not when compared with the millions who went to other destinations; but it has from the outset held plenty of qualitative interest, as I hope to have shown. Following on from the educated, skilled and gifted Italians who came to the UK as a migrant elite over centuries, and continued to do so in the 19th century when the Risorgimento became a factor, ordinary people with more in common with other Italian migrants in other international streams responded to new opportunities, notably in London. One of the factors in their success, the maintenance of a positive Italian identity in London for an ethnic minority 
that was growing and becoming more diffuse, was the infrastructure provided by the church and the exiles. In the latter case, it was a way of 'giving back' for the sanctuary and supports the asylum seekers had received through the Italophilia of the British upper classes. Despite the advantages of opting for migration to the UK in that period, there were many, one might imagine, who never achieved their dreams, who languished in poverty, succumbed to consumption or died in the cholera epidemics of Victorian London. For every successful return migrant, such as those that so impressed Leoni in his home village, there would have been many who returned with little to show for their time abroad, their health broken. These were the inevitabilities of engaging in the lottery of migration, then as now.

Are there any lessons in this case study for the migrants and asylum seekers of today? Most are new to their preferred destinations in Europe and other developed countries; they are still building their national or ethnic reputations in their destinations, usually in the face of prejudice, even racism and discrimination that may never be overcome. Although migrants from Africa and asylum seekers from the Middle-East lack the historical advantages of the Italians who have come to Britain, there may be ways in which they can turn their cultural characteristics to their advantage, to the benefit also of those who follow them. The example of the Italians in the UK shows that this is possible.

\section{References}

Ackroyd, P. (1969) London: the Biography, Random House, London.

Aldritch, H., Jones, T. and McEvoy, D. (1984) 'Ethnic advantage and minority business development', in Ward, R. and Jenkins, R. (Eds.): in Ethnic Communities in Business: Strategies for Economic Survival, pp.189-210, Cambridge University Press, Cambridge.

Balletta, F., Birindelli, A., Cerasi, F., Gesano, G., Golini, A., Malfatti, E., Ostuni, M., Rosoli, G., Saccheti, G., Sonnino, E. and Tassello, G. (1978) Un Secolo du Emigrazione Italiana: 1876-1976, Centro Studi Emigrazione, Rome.

Barrett, G. and McEvoy, D. (2006) 'The evolution of Manchester's 'curry mile': from suburban shopping street to ethnic destination', in Kaplan, D. and Li, W. (Eds.): Landscapes of the Ethnic Economy, pp.193-809, Rowman and Littlefield, Lanham, MD.

Barth, F. (1963) The Role of the Entrepreneur in Social Change in Northern Norway, Scandinavian University Books, Bergen.

Barth, F. (1969) Ethnic Groups and Boundaries: the Organisation of Cultural Difference, Universiteits for Iaget, Oslo.

Braudel, F. (1982) The Wheels of Commerce, Civilisation and Capitalism, Vol. II, Harper and Row, London.

Dana, L-P. and Morrisn, M. (2007) 'Towards a synthesis: a model of migrant and ethnic entrepreneurship', in Dana, L-P. (Ed.): Handbook of Research on Ethnic Minority Entrepreneurship, pp.803-812, Edward Elgar, Cheltenham.

Farley, N. (1969) Italians in London 1838-1905, Unpublished dissertation, London.

Foerster, R. (1919) The Italian Migration of Our Times, Harvard University Press, Cambridge, Mass.

Franzero, C.M. (1971) Ugo Foscolo a Londra, Guanda, Parma.

Garigue, P. and Firth, R. (1956) 'Kinship organisation of Italianates in London', in Firth, R. (Ed.): Two Studies of Kinship in London, The Athlone Press, London.

George, D. (1925) London Life in the XVIIIth Century, Kegan, Paul, Trench, Trubner and Co., London. 
Handlin, O. (1951) The Uprooted, Little, Brown, Boston.

Hannerz, U. (1974) 'Ethnicity and opportunity in Urban America', in Cohen, A. (Ed.): Urban Ethnicity, Tavistock, London.

Hobsbawm, E. (1962) The Age of Revolution, Europe: 1789-1848, Weidenfield and Nicholson, London.

Hobsbawm, E. (1975) The Age of Capital: 1848-1875, Weidenfield and Nicholson, London.

Hobsbawm, E. (1987) The Age of Empire: 1875-1914, Weidenfield and Nicholson, London.

Inwood, S. (1998) A History of London, Macmillan, London.

Italian Chamber of Commerce (1895) Elenco Generale degli Italiani Residenti nel Regno Unito/Commercial and Professional Italians established in the UK, London.

Jenkins, R. (1984) 'Ethnicity and the rise of capitalism in Ulster', in Ward, R. and Jenkins, R. (Eds.): in Ethnic Communities in Business: Strategies for Economic Survival, pp.57-72, Cambridge University Press, Cambridge.

Leoni, P. (1966) I shall Die on the Carpet, Frewin, London.

Light, I. (2007) 'Global entrepreneurship and transnationalism', in Dana, L-P. (Ed.): Handbook of Research on Ethnic Minority Entrepreneurship, pp.3-15, Edward Elgar, Cheltenham.

Marin, U. (1969) Emigrazione Italiana in Gran Bretagagna, Centro Studi Emigrazione, Rome.

Marin, U. (1975) Italiani in Gran Bretagna, Centro Studi Emigrazione, Rome.

Mars, G. and Nicod, M. (1984) The World of Waiters, George Allen and Unwin, London.

Maugham, S. (1952) 'Introduction', in Maugham, S. (Ed.): A Choice of Kipling's Prose, Macmillan, London.

Mayhew, H. (1851-1968) London Labour and the London Poor: Volumes I-III, Dover Publications, London.

Nichols, P. (1973) Italia, Italia, Macmillan, London.

Palmer, R. (1977) 'The Italians: patterns of migration to London', in Watson, J.L. (Ed.): Between Two Cultures, Migrants and Minorities in Britain, pp. 242-268, Basil Blackwell, Oxford.

Palmer, R. (1980) 'Processes of estrangement and disengagement in an Italian emigrant community', New Community: Journal of the Commission for Racial Equality, Vol. 8, No.3, pp.277-287.

Palmer, R. (1981) The Britalians: An Anthropological Investigation, D. Phil. dissertation, University of Sussex, UK.

Palmer, R. (1984) 'The rise of the Britalian culture entrepreneur', in Ward, R. and Jenkins, R. (Eds.): in Ethnic Communities in Business: Strategies for Economic Survival, pp.89-104, Cambridge University Press, Cambridge.

Palmer, R. (1991) 'Migration, encapsulation and ethnicity: Italian villagers in London', in Spiegel, A. and McAllister, P. (Eds.): Tradition and Transition in Southern Africa, African Studies [Fiftieth Anniversary Volume], Vol. 50, Nos. 1\&2, pp.87-102, Witwatersrand University Press, Johannesburg.

Palmer, R. (2007) 'Italians in Britain: Britalian culture entrepreneurs revisited', in Dana, L-P. (Ed.): Handbook of Research on Ethnic Minority Entrepreneurship, pp.360-374, Edward Elgar, Cheltenham.

Porter, R. (1958) 'Foreword', in Inwood, S. (Ed.): A History of London, Macmillan, London.

Price, C. (1963) Southern Europeans in Australia, Oxford University Press, Melbourne.

Smith, D.M. (1959) Italy: a Modern History, University of Michigan Press, Ann Arbor.

Sponza, L. (1988) Italian Immigrants in Nineteenth Century Britain: Reality and Images, Leicester University Press, Leicester. 
Stearns, P. (2012) Rethinking the Long 19th Century in World History: Assessments and Alternatives, World History Connected [online] http://worldhistoryconnected.press.illinois.edu/9.3/forum_stearns.html (accessed 17 October 2016).

The Mazzini-Garibaldi Club of London [online] http://www.mazzinigaribaldiclub.org/ (accessed 28 October 2016).

The Slippery Concept of Lumpenproletariat [online] http://moufawad-paul.blogspot.co.za/2012/06/ slippery-concept-of-lumpenproletariat.html (accessed 1 November 2016).

Towner, J. (1985) 'The grand tour: a key phase in the history of tourism', Annals of Tourism Research, Vol. 12, No. 3, pp.297-333.

Tranter, N. (1994) 'Population, migration and labour supply', in Aldcroft, D. and Ville, S. (Eds.): The European Economy 1750-1914: A Thematic Approach, Manchester University Press, Manchester.

Veblen, T. (1899) The Theory of the Leisure Class: An Economic Study of Institutions, The Macmillan Company, New York.

Volery, T. (2007) Ethnic Entrepreneurship: a Theoretical Framework, In Dana, L-P. (Ed.): Handbook of Research on Ethnic Minority Entrepreneurship, pp.30-41, Edward Elgar, Cheltenham.

Wallerstein, I. (1980) The Modern World-System, vol. II: Mercantilism and the Consolidation of the European World-Economy, 1600-1750, Academic Press, New York.

Watson, J. (1975) Emigration and the Chinese Lineage: the Mans in Hong Kong and London, University of California Press, Berkeley.

Werbner, P. (1984) 'Business on trust: Pakistani entrepreneurship in the Manchester garment trade', in Ward, R. and Jenkins, R. (Eds.): in Ethnic Communities in Business: Strategies for Economic Survival, pp.166-188, Cambridge University Press, Cambridge.

Wicks, M. (1937) The Italian Exiles in London, Manchester University Press, Manchester.

Wilson, A.N. (2002) The Victorians, Hutchinson, London.

Zucchi, J. (1992) The Little Slaves of the Harp: Child Street Musicians in Nineteenth Century Paris, London and New York, McGill University Press, Montreal and Kingston.

\section{Notes}

1 Marin (1975) cites the names of the most prominent activists who arrived: Mazzini, Panizzi, Rosetti, Pecchio, Saffi, Lacaita, Crispi, Gallenga, Pepe, Settembrini, di Salitarosa, Arrivabene, Spaventa, the Ruffini brothers, Berchet, Pisacane, dal Pozzo, Mossotti, Pilo, Radici and Ciani.

2 One of the exiles, Gabriele Rossetti was a poet and Dante scholar and, from 1831, Professor of Italian at King's College, London. His wife, Frances Polidori, was a teacher, whose father was Italian and mother English. Their son, Dante Gabriel Rossetti (1828-1882), was a poet as well as an artist who co-founded the Pre-Raphaelite Brotherhood, and was one of the drivers of Italianate style in the latter Victorian period [Wilson, (2002), Ch. 13]. 